\title{
The Marketing Strategies of HNI HPAI (International Halal Network - Herba Penawar Alwahida Indonesia) as an Effort to Survive the Covid-19 Pandemic
}

\author{
Ruslaini $^{1}$, Abizar $^{2}$, Nina Ramadhani Wulandari ${ }^{3}$ \\ \{rosimuhammadiyahlampung@gmail.com ${ }^{1}$ \} \\ Universitas Muhammadiyah Lampung, Lampung, Indonesia ${ }^{1,2,3}$
}

\begin{abstract}
The Covid -19 Pandemic has demanded companies to determine an appropriate marketing strategy with changes in business interaction between companies and customers without holding direct events as it is forbidden- however, the companies can still be productive to provide the latest information to their customers. Marketing strategy during pandemic that refers to the marketing mix of the $7 \mathrm{P}$ concepts (product, price, place, promotion, people or participant, process, and physical evidence). This study aims to analyze the marketing strategies being implemented by HNI HPAI, as well as to identify and analyze the company's internal and external factors using a SWOT analysis, with the results as follows: the analysis showed that during the pandemic, HNI HPAI has been focusing on establishing several technological instruments that are able to encourage and improve the company's performance in terms of its service and convenience in accordance with the five (5) pillars of company, while the results of the SWOT matrix showed that the usefulness and the development of HNI HPAI has been implemented to participate in contributing to the national economic development by cooperating with small and medium entrepreneurs. The process of marketing strategy and services were carried out with the principles of honesty, sincerity, fairness and trust.
\end{abstract}

Keywords: Marketing strategy, Survive, Covid-19 pandemic

\section{Introduction}

The Covid -19 Pandemic period requires every company to determine the most appropriate strategy to remain productive and to provide a lot of current information to its customers. It is expected to encourage the company to create and determine the most appropriate strategy, including a marketing strategy using technology in interactions and providing company's information to its customers during the pandemic, with a marketing strategy that refers to the concept of marketing mix of the $7 \mathrm{P}$ (product, price, place, promotion, person or participant, process, physical evidence). This research aims to analyze the marketing strategies implemented by HNI HPAI (Halal Network International - Herba Penawar Alwahida Indonesia) and to analyze the company's internal and external factors using SWOT analysis [1]. During this pandemic, the focus is on building several technological instruments that are able to encourage and improve company's performance in terms of services which refers to the five (5) PILLARS of the company. 


\section{Method}

This research used qualitative methods by collecting the interview data, observation and documentation [2] related to the current conditions, the Covid-19 Pandemic. The observations were carried out with direct involvement of the researchers and live streaming on HNI social media channels; Youtube, HNI Official, Facebook, and Instagram that was also directly carried out by HNI Lampung during the research. The analyzing Marketing strategies was done with reference to the $7 \mathrm{P}$ concepts (product, price, place, promotion, people or participant, process, physical evidence). The following step was done by the researchers by utilizing all information into the categories of internal and external factors, namely compiling the strength and weakness factors as well as opportunities and threats, then compiling the IFAS matrix (internal strategic factor analysis summary) and the EFAS matrix (external strategic factor analysis summary), finally the SWOT analysis graph was done to determine the complete and accurate position and strategy.

\section{Results and discussion}

In determining the marketing strategy, the company must first look at the market situation and conditions as well as market conditions and assess its position in the market [3]. In this section, some primary data from the interviews will be presented in a marketing strategy that refers to the marketing mix of the $7 \mathrm{P}$ concept (product, price, place, promotion, people or participant, process, physical evidence). In its application, HNI has been implementing this $7 \mathrm{p}$ marketing strategy into the 5 pillars of the company, namely products, stock agents (price, place, promotion, process), Support System (Process), Technology (Process), Management Integrity (people, physical evidence,) expanding the market and increasing the capacity and knowledge and information of the company to consumers during the Covid -19 pandemic, HNI is very concerned about the five (5) pillars strategies that are focused on building the strength of support (Information Technology) that are qualified, informative, easily accessible, safe, and available to everyone. These strategies show in Figure 1.

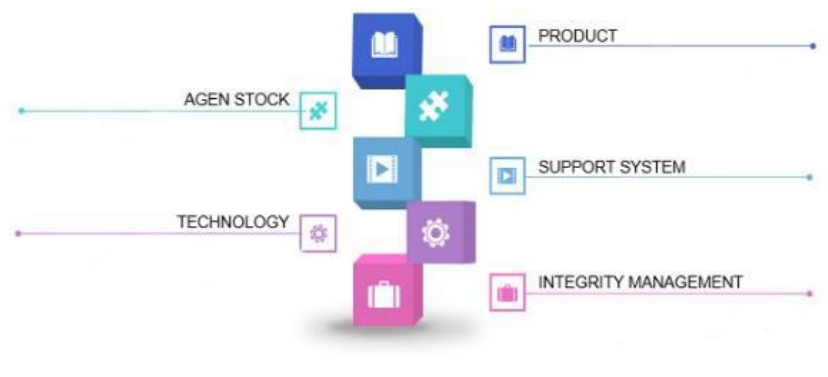

Fig. 1. 5 Pillars (P.A.S.T.I)

The next step is the preparation of IFAS as a picture of the company's internal conditions, which are described as strengths and weaknesses that show the values and the rating of each factor (Table 1). Finally, it is the time to prepare EFAS matrix as a mapping of the external 
conditions of HNI through opportunity and threat factors. This matrix describes the conditions of the business opportunity that you have (Table 2).

Table 1. Business opportunity

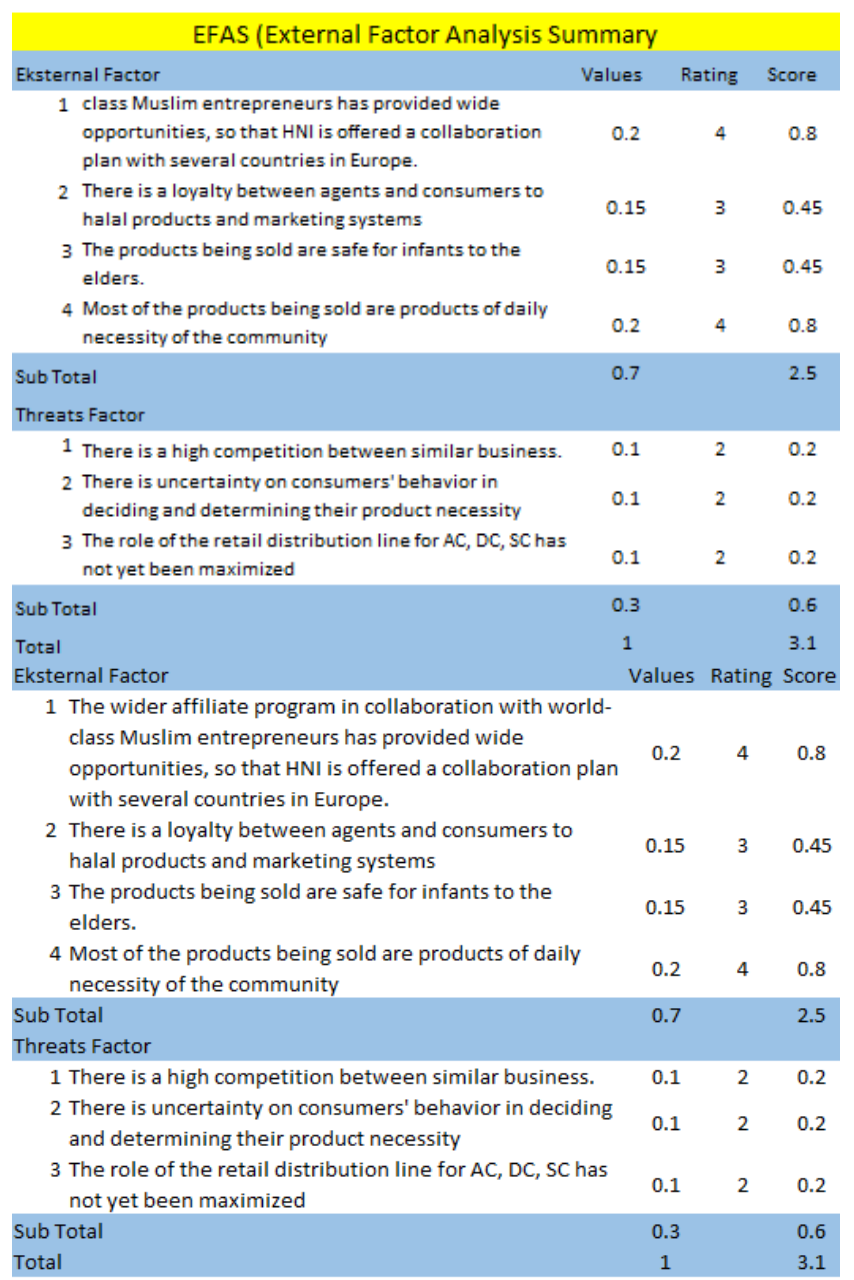

Based on the results of the calculation, the internal strength factor possessed by HNI is greater than the weakness factor, which is 1.96 , where the number 1.96 is the gain from the total strength of 2.54 with a total weakness of 0.58 , and for external factors the opportunity of HNI HPAI is greater than the threat factor. The number 1.9 is the gain from the total opportunity of 2.5 with a total threat of 0.6 . This calculation can be used to draw an appropriate marketing strategy formulation. 


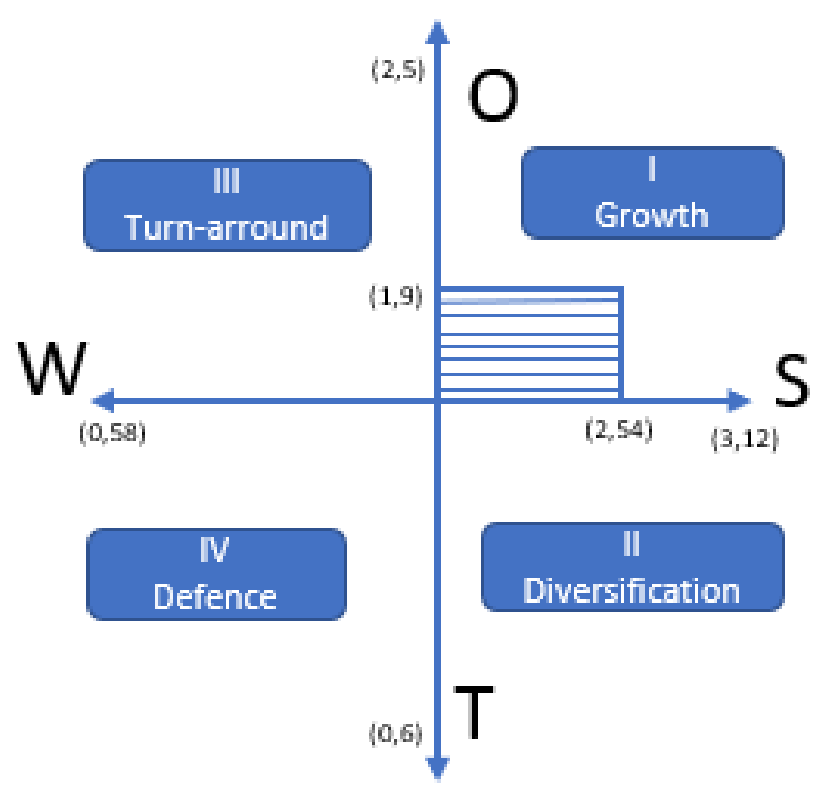

Fig. 2. SWOT Matrix

Figure 2 is a matrix that is compiled using the strengths, weaknesses, opportunities and threats variables identified in the internal and external strategic factors. This SWOT matrix illustrates how opportunities and threats from the company's external environment can be adjusted to the strengths and weaknesses of the company. The SWOT matrix model analysis used the data obtained from the internal and the external strategy factor of HNI HPAI.

Table 2. SWOT Matrix of IFAS

\begin{tabular}{|c|c|c|}
\hline & Strength (S) & Weakness (W) \\
\hline IFAS & $\begin{array}{l}1 \text { The products being sold are of the best quality } \\
\text { with complete MUI licenses and certificates. } \\
2 \text { The price of the product being sold is competitive } \\
\text { and able to compete } \\
3 \text { The location of BC, AC and Agen stock are } \\
\text { accessible. } \\
4 \text { Promotional activities are well planned with the } \\
\text { use of all aspects } \\
5 \text { There is a strong bond between agents and team } \\
6 \text { There is a Market Place to support the needs of } \\
\text { UMKM products. } \\
7 \text { There is a good reputation and positive image of } \\
\text { the company towards agents and costumers. }\end{array}$ & $\begin{array}{l}1 \text { There are agents and stock centers that do not comply } \\
\text { with the code of ethics } \\
2 \text { HNI was formed in 2012, it has not reached } 10 \text { years } \\
3 \text { The discrepancy between the company's goals and the } \\
\text { attitude of the agents in achieving the goals formulated } \\
\text { by the company. }\end{array}$ \\
\hline
\end{tabular}


S Strategy

1. The expanding affiliate program in collaboration with world-class Muslim entrepreneurs has provided wide opportunities, resulted in HNI is offered a collaboration plan with several countries in Europe.

2. There is a loyalty between agents and consumers to halal products and marketing systems

3. The products being sold are safe for infants and the elders

4. Most of the products being sold are products of daily necessity of the community

5. There is a good relationship between the management, leaders and Partners / AB

6. The products being sold are appropriate for all ages, from infants to the elderly

\section{Threat (T)}

1. There is a high competitio between HNI and other similar businesses

2. There is uncertainty on consumers' behavior in deciding and determining where to shop

3. The business partners were less cooperative in completing their obligations

\section{SO Strategy}

1. Maintaining and improving the quality of products - the products continue to foster and add affiliates so that they can forge more cooperation, especially with the aim of expanding in the international world

2. Maintaining the loyalty of partners and end customers

3. Strengthening relationships with partners and members as well as general costumers to maintain a good relationship.

4. HNI has made some new breakthroughs in terms of knowledge, partner development and promotion of its products

\section{WO Strategy}

1. Administering vision and mission, socializing the agency code of ethics from the leader to the partners $(\mathrm{AB})$ through training to reach the same goals and compliance with the agency code of ethics simultaneously at the concept and application level to increase community trust and benefi
St Strategy

1. Improving the quality of the products being sold, maintaining competitive prices, satisfying service, developing the promotions both from the media and the information, creating a presentation technique as attractive as possible in order to be recalled in the hearts of the consumers.

2. Approaching the consumers through activities at certain events and conducting sales promotions to attract the consumers to make purchases

3. Increasing a better communication to the business partners, improving supervisory functions and reducing uncooperative partners.

\section{WT Strategy}

MBC Swalayan continues to foster and improve the quality of internal and external relationships in order to build a good synergy, so it can outperform any competition in similar businesses

Fig. 3. SWOT Analysis of HNI HPAI 
Figure 3 shows that a company's performance can be determined by a combination of internal and external factors. The combination of these two factors is shown in the diagram of the SWOT analysis results as follows:

- SO strategy (supporting Aggressive strategy), namely by: maintaining product quality as evidenced by the completeness of permits and halal certificates of the MUI. Strengthening the relationships with partners in order to create a good relationship. Increasing agent loyalty and solidity with team leaders. HNI continues to innovate, especially during the Covid-19 period, which continues to upgrade its technology which will provide satisfactory services that can be accessed from any place, automatically in real-time setting.

- WO strategy (Supporting Turn-Around Strategy), namely: HNI always pays close attention to the distribution channels, gives rewards to agents who excel their performances and have high loyalty to the company, conducts training and consultations both offline and online in order to maintain and improve the skills and knowledge of agents.

- ST Strategy (Supporting Diversification Strategy), namely: Innovating its technology so that it is easy to be accessed. Increasing and expanding the marketing network by holding certain promotions for SC, DC, AC, on events held by HNI. HNI is expected to improve the knowledge on the code of ethics to its agents in providing information related to company ethics to its agents, and its distribution channels, so that they always follow the code of ethics of HNI HPAI agency, as well as to minimize any noncompliance occurs in the field.

- WT Strategy (Supporting Defensive Strategy), namely: HNI continues to improve the quality of the company's internal and external relations in order to outperform competition with similar companies. The maintained quality of internal and external relations improves their integrity, enabling HNI to dominate the competition

\section{Conclusion}

Based on the results of the above research, it can be concluded that in planning and carrying out marketing strategies during the Covid-19 period, HNI is very concerned with the $7 \mathrm{P}$ marketing mix strategy through the implementation of the five (5) pillars of the company, namely: Product quality, distribution channels, support system in order to succeed in the marketing plan, technology which builds a structure as a centralized information service, and management integrity to increase professionalism and grow public trust. Based on the company's internal and external analysis, it can be concluded that the Growth Strategy is the key determination and the systematic setting of HNI marketing strategy. HNI is able to maintain and improve the quality of its products in order for making repeat purchases by the costumers as well as HNI agents. Finally, parts of the SWOT matrix results can be concluded by several developments with the considerations of internal and external factors.

\section{References}

[1] Rangkuti.Freddy, Analisis SWOT Teknik Membedah Kasus Bisnis, Jakarta:PT.Gramedia Pustaka Utama, 2008. 
[2] Moleong.Lexy J., Metodelogi Penelitian Kualitatif, Bandung: PT. Remaja Rosdakarya, cet. 29, 2011.

[3] Khotijah.Siti, Smart Strategy of Marketing, Bandung: ALFABETA, 2004. 